\title{
Should human chorionic gonadotropine treatment increase thyroid volume?
}

Ayten Oguz', Dilek Tuzun', Murat Sahin', Nese Bulbul', Ahmet Celik ${ }^{2}$, Numan Guvenc ${ }^{3}$, Elif Inanc ${ }^{4}$, Kamile Gul'

${ }^{1}$ Kahramanmaras Sutcu Imam University, Faculty of Medicine, Department of Endocrinology and Metabolism, Kahramanmaras, Turkey

${ }^{2}$ Kahramanmaras Sutcu Imam University, Faculty of Medicine, Department of Biochemistry, Kahramanmaras, Turkey ${ }^{3}$ Kahramanmaras Sutcu Imam University, Faculty of Medicine, Department of Family Medicine, Kahramanmaras, Turkey

${ }^{4}$ Kahramanmaras Sutcu Imam University, Faculty of Medicine, Department of Internal Medicine Kahramanmaras, Turkey

\section{Correspondence to:}

Ayten Oguz

Kayseri Yolu $10 \mathrm{~km}$

Avşar Kampüsü Kahramanmaraş

Sütçü Imam Üniversitesi

46100 - Kahramanmaras, Turkiye

aytenoguz@windowslive.com

Received on June/19/2015

Accepted on July/1/2015

\begin{abstract}
Objective: Our aim was to investigate the thyroid function tests and thyroid volume differences among males with isolated hypogonadotropic hypogonadism $(\mathrm{IHH})$ who take androgen replacement treatment (ART). Materials and methods: Forty-four male with IHH with a mean age 33.2 (18-54), diagnosed in Endocrinology and Metabolism Department between September 2013 and September 2014 and 40 healthy male control with a mean age 27.77 (18-55) were involved to study. Patient group was divided to testosterone-treated patients $(n=19)$ and human chorionic gonadotropine (hCG)treated patients $(n=25)$. Patient group was compared in terms of total testosterone, thyroid function tests [thyroid stimulating hormone (TSH), free thyroxine $\left(\mathrm{fT}_{4}\right)$ ] and thyroid volume, before and 6 months after treatment. Patient group was compared with control group as well. Results: When we compared the patient group with the control group, there was no significant difference for age, Body mass index, $\mathrm{TSH}_{1} \mathrm{fT}_{4}$ and thyroid volume between two groups before treatment. There was no difference in terms of TSH, but $\mathrm{fT}_{4^{\prime}}$ testosterone levels and thyroid volume were significantly higher after treatment, when the patient group was compared before and after treatment $(p<0.05)$. When we compared testosterone-treated patients and hCG-treated patients; thyroid volume was higher among hCG-treated patients $(p=0.001)$ but there was no difference for thyroid volume before and after testosterone treatment $(p>0.05)$. There was no statistically significant correlation between testosterone levels with $\mathrm{TSH}_{1} \mathrm{fT}_{4}$ and thyroid volume $(r=0.09, \mathrm{p}=0.32 ; r=0.14, \mathrm{p}=0.11 ; \mathrm{r}=0.15$, $p=0.09$, respectively). Conclusion: Our study showed that ART increases the thyroid volume especially in hCG-treated patients. Therefore, we suggest that thyroid volume changes should be followed up in hCG-treated patients. Arch Endocrinol Metab. 2015;59(6):482-6
\end{abstract}

\section{Keywords}

Thyroid volume; thyroid stimulating hormone; human chorionic gonadotropin

\section{INTRODUCTION}

I solated hypogonadotropic hypogonadism (IHH) may present as an isolated hormonal deficiency (low testosterone and low or normal levels of gonadotropins) secondary to hypothalamic or pituitary defects (1). The goals of therapy for IHH in adolescent or young adult males include the induction of normal puberty and testicular development that allow future fertility. Androgen replacement treatment (ART) that includes testosterone and gonadotropins are used in these patients (2).

Human chorionic gonadotropin (hCG) is a glycoprotein hormone that has structural similarity to thyroid stimulating hormone (TSH). The beta subunit of hCG is unique to hCG but alpha-subunit is identical to that luteinizing hormone (LH), follicle stimulat- ing hormone (FSH) and TSH (3). Human chorionic gonadotropin has thyroid-stimulating activity in bioassays in mice, rats, chicks and men (4-6). The thyroid-stimulating activity of a commercial preparation of hCG was first demonstrated by Burger in a mouse bioassay (7). Subsequently, thyrotrophic activity has been found in several hCG preparations $(4,5)$. These studies showed that hCG is the molar TSH and that 1 Unite hCG has intrinsic thyrotrophic activity equivalent to approximately $0.5 \mu \mathrm{U}$ TSH in the Mouse bioassay (4). Additionally, hCG stimulates iodide uptake, adenylate cyclase, and DNA synthesis in cultured rat thyroid cells (8). Many investigations have detected that hCG and TSH share not only structural homology but also their receptors show structural similarity as well, and this homology suggests the basis for 
the reactivity of hCG with the TSH receptor $(9,10)$. Therefore, high hCG concentrations are associated with thyroid stimulation, both functionally (lower serum TSH concentrations) and anatomically (increased thyroid volume) (11).

There are several conflicting results about the effect of ART on thyroid function tests among males with hypogonadism. Several studies also showed that androgen administration may be associated with increased (12), decreased (13) or unaltered (14) TSH response to thyrotropin-releasing hormone (TRH). But most studies evaluated only patients with primary hypogonadism. So we aimed to investigate whether both hypogonadism and ART (especially hCG) effect the thyroid function tests and thyroid volume in males with IHH.

\section{MATERIALS AND METHODS}

Male patients with IHH and healthy male controls who were admitted to Endocrinology and Metabolism Clinic at Kahramanmaras Sutcu Imam University Hospital were included in the study. The study was approved by the ethics committee of Kahramanmaras Sutcu Imam University.

\section{Subjects and study protocol}

Forty-four male with IHH (patient group) with a mean age 33.2 (18-54) that was diagnosed in Endocrinology and Metabolism Department in Kahramanmaras (a mild iodine deficient city in Turkey) between September 2013 and September 2014 and 40 healthy male control (control group) with a mean age 27.77 (18-55) were involved to study. Patient group was divided into two goups; treated with testosterone $(\mathrm{n}=19)$ and HCG group $(n=25)$. Patient group was compared in terms of body mass index (BMI), total testosterone (TT), thyroid function tests $\left[\mathrm{TSH}\right.$, free thyroxine $\left.\left(\mathrm{fT}_{4}\right)\right]$ and thyroid volume, before and 6 months after treatment. These parameters were evaluated between patient and control group as well.

\section{Inclusion criteria}

Isolated hypogonadotropic hypogonadism was defined as the presence of clinical symptoms related to hypogonadism (e.g. incomplete or delayed sexual development, reduced libido and erectile dysfunction/infertility) and low serum TT levels $(<250 \mathrm{ng} / \mathrm{dL})$, insufficient $\mathrm{LH}$ (i.e. low or non-elevated levels), the absence of any other anterior and/or posterior pituitary hypofunction and pathological findings on a pituitary magnetic resonance image (1).

\section{Exclusion criteria}

Patients with previously known history of thyroid disease or receiving any drugs affecting thyroid gland, those with hyperthyroidism, primary or secondary hypothyroidism, euthyroid or hypothyroid Hashimato's disease, thyrotoxicosis (factitia, subacute thyroiditis), and those receiving L-thyroxin suppression therapy, bromocriptine, somatostatin, anti-thyroid drugs, lithium, interferon, perchlorate, and sulfonamides were excluded. Moreover, patients who underwent radiological examination with an iodinated contrast medium within at least 3 days, those who last received drugs including iodine 7 days ago, and those who underwent thyroid operation or received radioactive iodine were not included in the study. Patients with systemic illnesses were excluded, in addition to those who took excessive exercise, used certain medications or as these could affect the metabolism of testosterone and testosterone levels. Secondary causes of hypogonadotropic hypogonadism, such as panhypopituitarism, hyperprolactinaemia and intracranial masses, were excluded before making a diagnosis of IHH.

\section{Biochemical analyses}

Blood samples was collected in the morning between 08.00-09.00 hours after an overnight fast to avoid differences because of diurnal variation, especially for hormonal parameters. Normal reference values were as follow FSH $(1.42-15.4 \mathrm{mIU} / \mathrm{ml}), \mathrm{LH}(1.24-7.8 \mathrm{mIU} / \mathrm{mL})$, TT (280-1100 ng/dL), prolactin $(3-14.7 \mathrm{ng} / \mathrm{mL})$, TSH $(0.4-4.2 \mu \mathrm{IU} / \mathrm{mL}), \mathrm{fT}_{4}(0.8-2.7 \mathrm{ng} / \mathrm{dL})$ and Cortisol $(5-23 \mu \mathrm{g} / \mathrm{dL})$. Hormone analyses were carried out using chemiluminescence enzyme immunoassay (Immulite 2000, Diagnostic Products Corporation, Los Angeles, CA, USA, or UniCel DxI 800, Beckman Coulter CA, USA) commercial kits.

\section{Conventional thyroid ultrasonography}

Conventional thyroid ultrasonography (US) was performed before and 6 month after the treatment. Each participants underwent a preliminary ultrasonography and it was investigated whether there was any abnormality such as a nodule or parenchymal heterogeneity. All grey scale measurements were performed by the same 
endocrinologist with the same US device (Logic P5 System, GeneralElectric Medical Systems, Milwaukee, WI, USA) using a linear transducer of $12 \mathrm{MHz}$ width. While the participant was lying in supine position with the neck in hyperextension, the skin was covered with acoustic material. The thyroid gland was scanned in three dimensions. Depth, width (in transverse plane), and length (in longitudinal plane) of each lobe were measured. Volume of each lobe was calculated using the formula, volume $(\mathrm{mL})=\pi / 6 \mathrm{x}$ width $\mathrm{x}$ depth $\mathrm{x}$ length (15). Total volume was determined as the sum of the volumes of the lobes except for the isthmus.

\section{Statistical evaluation}

The SPSS for Windows (ver. 11.0.; Chicago, IL, USA) was used for statistical analysis. The Student's t-test was used to compare independent variables and dependent variables that were in accordance with a normal distribution, and the variables were expressed as the mean \pm standard deviation. Direct relationship between variations was evaluated with pearson correlation test. $\mathrm{P}<$ 0.05 was defined as statistically significant.

\section{RESULTS}

Forty-four male patients with IHH and 40 healthy male controls were involved to the study. The baseline characteristics and thyroid function tests, TT levels, thyroid volume of the male patient with IHH and control group are summarized in table 1 . There was no significant difference in terms of age, $\mathrm{BMI}, \mathrm{TSH}, \mathrm{fT}_{4}$ and thyroid volume between control group and pretreatment patient group $(\mathrm{p}<0.05)$, but TT levels were significantly lower in patient group $(\mathrm{p}<0.05)$.

Total testosterone levels, thyroid function tests and thyroid volume changes, before and after treatment, in patient group were summarized in table 2 . In patient group, there was no significant difference according to TSH levels, before and after treatment $(\mathrm{p}>0.05)$, but $\mathrm{fT}_{4}$, TT levels and thyroid volume $(8.76 \pm 1.13$ $\mathrm{mL}$ and $9.02 \pm 0,99 \mathrm{~mL}$; before and after treatment, respectively) were significantly higher after treatment $(\mathrm{p}=0.001)$.

We also analyzed the patients according to the treatment type (Table 3 ). In hCG-treated group, thyroid volume was significantly higher after treatment $(8.28 \pm$

Table 1. The baseline characteristics and thyroid function tests, total testosterone levels, thyroid volume of the male patients with $\mathrm{HH}$ and controls

\begin{tabular}{|c|c|c|c|}
\hline Parameters & Patient group $(n=44)$ & Control group $(n=40)$ & $\mathbf{p}$ \\
\hline Age (year) & $32.47 \pm 9.30$ & $28.77 \pm 9.68$ & 0.078 \\
\hline $\mathrm{BMl}\left(\mathrm{kg} / \mathrm{m}^{2}\right)$ & $27.33 \pm 6.61$ & $26.5 \pm 7.06$ & 0.605 \\
\hline $\mathrm{FSH}(\mathrm{mlU} / \mathrm{mL})$ & $1.82 \pm 1.68$ & $5.1 \pm 2.21$ & $<0.001$ \\
\hline $\mathrm{LH}(\mathrm{mlU} / \mathrm{mL})$ & $1.44 \pm 1.24$ & $3.71 \pm 1.50$ & $<0.001$ \\
\hline$\Pi \mathrm{T}(\mathrm{ng} / \mathrm{dL})$ & $98.65 \pm 69.69$ & $460.52 \pm 90.36$ & $<0.001$ \\
\hline $\mathrm{TSH}(\mathrm{mlU} / \mathrm{mL})$ & $1.41 \pm 0.79$ & $1.70 \pm 0.94$ & 0.133 \\
\hline $\mathrm{fT}_{4}(\mathrm{ng} / \mathrm{dL})$ & $1.16 \pm 0.19$ & $1.10 \pm 0.14$ & 0.128 \\
\hline Prolactin (ng/mL) & $7.64 \pm 3.39$ & $7.85 \pm 2.77$ & 0.772 \\
\hline Cortisol (mcg/dL) & $19.23 \pm 1.14$ & $19.36 \pm 1.22$ & 0.623 \\
\hline $\mathrm{GH}(\mathrm{ng} / \mathrm{mL})$ & $1.86 \pm 0.55$ & $2.04 \pm 0.75$ & 0.261 \\
\hline $\mathrm{TV}(\mathrm{mL})$ & $8.62 \pm 1.46$ & $8.78 \pm 0.81$ & 0.558 \\
\hline
\end{tabular}

IHH: Isolated hypogonadotropic hypogonadism; BMI: body mass index; FSH: follicle stimulating hormone; LH: luteinizing hormone; T: total testosterone; TSH: thyroid stimulating hormone; $\mathrm{fT}_{4}$ : free thyroxine; GH: growth hormone; TV: thyroid volume.

Table 2. Total testosterone levels, thyroid function tests and thyroid volume changes before and after treatment in patient group

\begin{tabular}{lccc}
\hline Parameters & Before treatment $\mathbf{n}=\mathbf{4 4}$ & After treatment $\mathbf{n}=\mathbf{4 4}$ & $\mathbf{p}$ \\
\hline $\mathrm{BMl}\left(\mathrm{kg} / \mathrm{m}^{2}\right)$ & $27.3 \pm 3.90$ & $27.1 \pm 5.10$ & 0.620 \\
$\mathrm{TT}(\mathrm{ng} / \mathrm{dL})$ & $98.65 \pm 69.70$ & $434.83 \pm 138.64$ & $<0.001$ \\
$\mathrm{TSH}(\mathrm{mll} / \mathrm{mL})$ & $1.45 \pm 0.75$ & $1.39 \pm 0.56$ & 0.627 \\
$\mathrm{fT}_{4}(\mathrm{ng} / \mathrm{dL})$ & $1.16 \pm 0.19$ & $1.34 \pm 0.49$ & 0.024 \\
$\mathrm{TV}(\mathrm{mL})$ & $8.76 \pm 1.13$ & $9.02 \pm 0.99$ & 0.001 \\
\hline
\end{tabular}

BMI: body mass index; TT: total testosterone; TSH: thyroid stimulating hormone; $\mathrm{fT}_{4}$ : free thyroxine; TV: thyroid volume. 
$1.04 \mathrm{~mL}$ and $8.68 \pm 0.95 \mathrm{~mL}$, before and after treatment, respectively) $(\mathrm{p}=0.001)$, but in group treated with testosterone, thyroid volume was similar before and after treatment $(9.39 \pm 0.95 \mathrm{~mL}$ and $9.47 \pm 0.88$ $\mathrm{mL}$, respectively) ( $\mathrm{p}>0.05)$. There was no significant difference according to TSH levels in hCG-treated group compared before and after treatment $(\mathrm{p}>0.05)$, but there was a borderline significant higher $\mathrm{fT}_{4}$ levels after treatment $(\mathrm{p}=0.057)$. In group treated with testosterone, $\mathrm{fT}_{4}$ and TSH levels were not significantly different before and after treatment $(\mathrm{p}>0.05)$.

When we analysed both patient $(n=44)$ and control group $(n=40)$ there was no significant correlation between TT levels and TSH, $\mathrm{fT}_{4}$, thyroid volume $(\mathrm{r}=$ $0.09, \mathrm{p}=0.32 ; \mathrm{r}=0.14, \mathrm{p}=0.11 ; \mathrm{r}=0.15, \mathrm{p}=0.09$, respectively).

\section{DISCUSSION}

Isolated hypogonadotropic hypogonadism is a rare but treatable disease. Androgen replacement treatment (testosterone or gonadotropin treatment) have been used to in these patients (2). There was limited data about the effects of sex hormones and hCG on thyroid functions and thyroid volume among hypogonadal male patients (14,16-18). Spitz and cols. (16), evaluated the effect of estrogens and androgens on TSH secretion in hypogonadal male and female patients. Male patients showed a transient reduction in serum T4 during hCG therapy. In this study, the male patients with hypogonadism had TSH responses to TRH similar to those of the male controls. Sowers and cols. (17), found that there were no significant changes in serum T4, T3, or TSH in euthyroid men that was under hCG treatment in the supraphysiological doses. In this study, commercial hCG in doses of 100,000 and 150,000 IU produced a small thyroid-stimulating effect. Additionally, Burman and cols. (14), showed that testosterone treatment had no significant effect on any of thyroid parameters in the patients with the Klinefelter's syndrome. On the contrary, Morley and cols. (18), mentioned that androgen administration has been reported with decreased TSH responses to TRH in the men with primary hypogonadism. In our study, $\mathrm{TSH}$ and $\mathrm{fT}_{4}$ levels were similar between healthy controls and male patients with $\mathrm{IHH}$ (before treatment). After ART, TSH levels didn't change significantly but $\mathrm{fT}_{4}$ levels increased significantly. In subgroup analysis we detected that this $\mathrm{fT}_{4}$ increase was due to group treated with hCG, so we speculated that this increase may be due to thyrotrophic activity of hCG. In group treated with hCG, $\mathrm{fT}_{4}$ levels increased after treatment but still within the normal range and this may be the cause of similar TSH levels before and after treatment.

Hyperthyroidism or increased thyroid function have been reported in many patients with trophoblastic tumors. These cases, considerably increased hCG levels and suppressed TSH levels suggest that hCG has thyrotropic activity. Human chorionic gonodotropine and human TSH belong to the biochemically closely related glycoprotein hormone family, they are potentially cross-reactive at the receptor level (8). In vitro, hCG has a weak intrinsic thyroid-stimulating activity, being able to stimulate iodine uptake, generation of cAMP, $3,5,3$ '-triodothyronine secretion, and even growth of thyroid cells (19-21). In our study thyroid volume was similar between healthy control and male patients with IHH (before treatment). But after treatment thyroid volume significantly increased in patient group $(\mathrm{p}<$ 0.05 ). In subgroup analysis there was no thyroid volume difference in testosterone-treated group but in group treated with hCG there was a significant increase $(\mathrm{p}=0.001)$. We think that this change was due to thyroid-stimulating activity of hCG as well.

Table 3. Body mass index, total testosterone levels, thyroid function tests and thyroid volume changes according to the treatment type

\begin{tabular}{|c|c|c|c|c|c|c|}
\hline Parameters & $\begin{array}{c}\text { TT group } \\
\text { Pre-treatment } \\
n=19\end{array}$ & $\begin{array}{c}\text { TT group } \\
\text { Post-treatment } \\
n=19\end{array}$ & $\begin{array}{c}\text { HCG group } \\
\text { Pre-treatment } \\
\mathbf{n = 2 5}\end{array}$ & $\begin{array}{c}\text { HCG group } \\
\text { Post-treatment } \\
n=25\end{array}$ & $\mathbf{p}^{\star}$ & $\mathbf{p}^{\star \star}$ \\
\hline $\mathrm{BMI}\left(\mathrm{kg} / \mathrm{m}^{2}\right)$ & $28.9 \pm 5.1$ & $28.46 \pm 4.03$ & $27.5 \pm 6.6$ & $27.97 \pm 9.12$ & 0.834 & 0.915 \\
\hline TT (ng/dL) & $133.04 \pm 72.87$ & $446.10 \pm 155.24$ & $72.52 \pm 55.43$ & $426.26 \pm 127.23$ & $<0.001$ & $<0.001$ \\
\hline TSH (mlU/mL) & $1.65 \pm 0.88$ & $1.41 \pm 0.45$ & $1.30 \pm 0.60$ & $1.37 \pm 0.63$ & 0.296 & 0.540 \\
\hline $\mathrm{FT}_{4}(\mathrm{ng} / \mathrm{dL})$ & $1.21 \pm 0.19$ & $1.31 \pm 0.31$ & $1.12 \pm 0.18$ & $1.36 \pm 0.60$ & 0.227 & 0.057 \\
\hline TV (mL) & $9.39 \pm 0.95$ & $9.47 \pm 0.88$ & $8.28 \pm 1.04$ & $8.68 \pm 0.95$ & 0.374 & 0.001 \\
\hline
\end{tabular}

TT: total testosterone; HCG: human chorionic gonadotropin; BMl: body mass index; TSH: thyroid stimulating hormone; $\mathrm{fT}_{4}$ : free thyroxine; TV: thyroid volume.

${ }^{*}$ The statistical comparison of pre and post-treatment in the group treated with testosterone; ** The statistical comparison of pre and post-treatment in the group treated with HCG. 
Several physiological and pathological factors as iodine supply, age, sex, weight, height, BMI, and body surface area can influence thyroid volume (22). Thyroid volume is reported to increase dependent to age or body surface (23). In addition to, in an iodine replete area, thyroid volume was inversely related to the median urinary iodide (24). In our study, there was no significant difference according to BMI and age in patient and control group. The location of the participants was the Mediterranean region and this region is a mild iodine deficient area. So we don't think that this thyroid volume difference was due to age, BMI and iodine status.

In conclusion, this is the first study investigating changes on thyroid volume and thyroid function of ART in males with IHH. Our study showed that ART increases the thyroid volume especially in patients treated with hCG. Therefore, we suggest that thyroid volume changes should be followed in patients treated with hCG. More studies are required to explain the changes of thyroid volume in males with IHH.

Disclosure: no potential conflict of interest relevant to this article was reported.

\section{REFERENCES}

1. Bianco SD, Kaiser UB. The genetic and molecular basis of idiopathic hypogonadotropic hypogonadism. Nat Rev Endocrinol. 2009;5(10):569-76.

2. Silveira LF, Latronico AC. Approach to the patient with hypogonadotropic hypogonadism. J Clin Endocrinol Metab. 2013;98(5):1781-8.

3. Combarnous Y. Molecular basis of the specificity of binding of glycoprotein hormones to their receptors. Endocr Rev. 1992;13:670-91.

4. Nisula BC, Morgan FJ, Canfield RE. Evidence that chorionic gonadotropin has intrinsic thyrotropic activity. Biochem Biophys Res Commun. 1974;59(1):86-91.

5. Kenimer JG, Hershman JM, Higgins HP. The thyrotropin in hydatidiform moles is human chorionic gonadotropin. J Clin Endocrinol Metab. 1975;40(3):482-91.

6. Pekary AE, Azukizawa M, Hershman JM. Thyroidal responses to human chorionic gonadotropin in the chick and rat. Horm Res. 1983;17(1):36-42.

7. Burger A. Further studies on a thyroid stimulating factor in crude chorionic gonadotrophin preparations and in urine. Acta Endocrinol (Copenh). 1967;55(4):600-10.

8. Yoshimura M, Hershman JM. Thyrotropic action of human chorionic gonadotropin. Thyroid. 1995;5(5):425-34.
9. Nagayama Y, Rapoport B. The thyrotropin receptor 25 years after its discovery: new insight after its molecular cloning. Mol Endocrinol. 1992;6(2):145-56.

10. Fradkin JE, Eastman RC, Lesniak MA, Roth J. Specificity spillover at the hormone receptor--exploring its role in human disease. $\mathrm{N}$ Engl J Med. 1989;320(10):640-5.

11. Glinoer D, de Nayer $P$, Bourdoux $P$, Lemone $M$, Robyn $C$, van Steirteghem A, et al. Regulation of maternal thyroid during pregnancy. J Clin Endocrinol Metab. 1990;71(2):276-87.

12. Smals AG, Kloppenborg PW, Lequin RL, Beex L, Ross A, Benraad TJ. The pituitary-thyroid axis in Klinefelter's syndrome. Acta Endocrinol (Copenh). 1977;84(1):72-9.

13. Morley JE, Sawin CT, Carlson HE, Longcope C, Hershman JM. The relationship of androgen to the thyrotropin and prolactin responses to thyrotropin-releasing hormone in hypogonadal and normal men. J Clin Endocrinol Metab. 1981;52(2):173-6.

14. Burman KD, Dimond RC, Noel GL, Earll JM, Frantz AG, Wartofsky L. Klinefelter's syndrome: examination of thyroid function, and the TSH and PRL responses to thyrotropin-releasing hormone prior to and after testosterone administration. J Clin Endocrinol Metab. 1975;41(06):1161-6.

15. Hegedüs L. Thyroid ultrasound. Endocrinol Metab Clin North Am. 2001;30(2):339-60.

16. Spitz IM, Zylber-Haran EA, Trestian S. The thyrotropin (TSH) profile in isolated gonadotropin deficiency: a model to evaluate the effect of sex steroids on TSH secretion. J Clin Endocrinol Metab. 1983;57(2):415-20.

17. Sowers JR, Hershman JM, Carlson HE, Pekary AE. Effect of human chorionic gonadotropin on thyroid function in euthyroid men. J Clin Endocrinol Metab. 1978;47(4):898-901.

18. Morley JE, Sawin CT, Carlson HE, Longcope C, Hershman JM. The relationship of androgen to the thyrotropin and prolactin responses to thyrotropin-releasing hormone in hypogonadal and normal men. J Clin Endocrinol Metab. 1981;52(2):173-6.

19. Hershman JM, Lee HY, Sugawara M, Mirell CJ, Pang XP, Yanagisawa $\mathrm{M}$, et al. Human chorionic gonadotropin stimulates iodide uptake, adenylate cyclase, and deoxyribonucleic acid synthesis in cultured rat thyroid cells. J Clin Endocrinol Metab. 1988;67(1): 74-9.

20. Davies TF, Platzer M. hCG-induced TSH receptor activation and growth acceleration in FRTL-5 thyroid cells. Endocrinology. 1986;118(5):2149-51.

21. Yoshimura $M$, Nishikawa M, Horimoto $M$, Yoshikawa N, Sawaragi $\mathrm{S}$, HorikoshiY, et al. Thyroid-stimulating activity of human chorionic gonadotropin in sera of normal pregnant women. Acta Endocrinol (Copenh). 1990;123(3):277-81.

22. Suzuki S, Midorikawa S, FukushimaT, Shimura H, OhiraT, Ohtsuru A, et al. Systematic determination of thyroid volume by ultrasound examination from infancy to adolescence in Japan:The Fukushima Health Management Survey. Endocr J. 2015;62(3):261-8.

23. Chanoine JP,Toppet $V$, Lagasse R, Spehl M, Delange F. Determination of thyroid volume by ultrasound from the neonatal period to late adolescence. Eur J Pediatr. 1991;150(6):395-9.

24. Delange F, Benker G, Caron P, Eber O, Ott W, Peter F, et al. Thyroid volume and urinary iodine in European schoolchildren: standardization of values for assessment of iodine deficiency. Eur J Endocrinol. 1997;136(2):180-7. 